\title{
THE IMPACT OF SOVEREIGN WEALTH FUND OWNERSHIP ON THE FINANCIAL PERFORMANCE OF FIRMS: THE EVIDENCE FROM EMERGING MARKETS
}

\section{Dariusz Urban}

\section{Introduction}

Sovereign Wealth Funds (SWFs) are still considered to be new-born institutional investors, in international financial markets, as well as innovative investment vehicles, despite their relatively long history. Several funds have been operating at a global level for more than fifty years, however the number of those created after the year 2000 represents the majority of the total in existence. For many years, these state-run funds have been almost anonymous investors, existing in the shadows, maintaining a low profile in the public eye. SWFs have been regarded as investment vehicles established in order to manage, in a rational and profitoriented way, pools of national wealth for future generations. These funds gained public attention during the last financial crisis, playing the role of investors of last resort for top global financial institutions. Nowadays, SWFs are among the most important institutional investors in global financial markets, and constitute a solid element in the architecture of the international financial safety net. Similarly to other financial institutions, Sovereign Wealth Funds possess huge amounts of capital. During the last decade the funds have doubled their assets under management, and, in spite of losses accrued in consequence of the last financial crisis, by the end of 2014 these amounted to over 7 billion US dollars. What distinguishes them the most from other financial institutions is the fact that they are owned, managed and controlled by sovereign states, have limited liquidity needs, a lower-than-market-average-level of redemption risk, a long-term, intergenerational investment horizon and relatively high risk tolerance. Sovereign Wealth Funds, because they are hybrid in nature, combine private sector methods of investment (e.g. coming from hedge funds and pension funds), with publicsector goals determined by governments.
Given the high level of opacity in SWFs' decision processing, the lack of transparency in their portfolio allocation, and their increasing capital involvement within a wide range of asset classes, a further understanding of the investment behavior of these state-run investment vehicles is sorely needed. In the last decade, several articles have been dedicated to analyzing the factors determining asset allocation among this group of investors, however there are issues which still need to be examined. One of the unanswered questions is the relation between purchasing equity stakes in companies, and changes in the financial performance of a targeted firm. The empirical findings have provided evidence that public companies, due to the fact that they cater to the interests of politicians and not only to their shareholders, are relatively less efficient with comparison to sole private firms. Thus these funds are likely to have objectives different than obtaining the highest possible financial return on an investment. In consequence, there are grounds to believe that companies owned by a SWF experience a reduction in their financial performance. The main goal of this paper is to answer the question of whether investment from Sovereign Wealth Funds determines changes in corporate financial performance.

This paper is part of a larger project aimed at understanding the financial aspects of SWFs' activity in emerging markets, especially as regards their investment practices and performance. Previous papers by the author have been focused on factors determining propensity to invest in companies listed on the Warsaw Stock Exchange and the Stock Exchange in Sao Paulo. This study contributes to ongoing research in the field of studies related to financial aspects of SWFs' behavior by providing empirical evidence about the impact of SWFs' investment in the corporate 
financial performance of targeted firms from the one of emerging markets in Central and Eastern European Countries.

The remainder of this paper is organized in the following manner: Section 1 provides theoretical background to the research by discussing the relation between institutional investor ownership and financial performance of the company. Section 2 describes the methodology and data used in this study. Section 3 presents and discusses empirical findings. The article concludes by pointing out avenues for future research.

\section{Literature Review}

\subsection{Institutional Investment in Global Financial Markets}

Privatization as a core government policy is not only well documented in economic literature, but has also been a key component of the transformation process in countries changing their economic format from one that is centrally planned to one that is market oriented. The issue of privatization is especially relevant to countries from Central and Eastern Europe, where from 1989 onwards, we can observe processes of massive retreat of states from many areas previously regarded a priori as state-owned and state-regulated. Moreover for several decades privatization along with deregulations in many sectors, has been the answer and the antidote given by leading global financial institutions to developing economies experiencing budget, financial or economic difficulties.

However, looking at the global picture as a whole, we can find evidence that over the 2001-2012 period governments acquired more assets through stock purchases than they sold through share issue privatizations and direct sales. The key factor that seems to explain these obvious contradictions is that the government purchases of equity have recently been conducted mostly by state entities acting as investors rather than owners. Much of this state investment was channeled through special investment vehicles - Sovereign Wealth Funds, and the vast bulk of stock purchases have been cross border transactions. SWFs have been buying non-controlling stakes in foreign and domestic companies in order to realize a longterm financial return, rather than to own and operate these businesses as state enterprises (Bortolotti, Fotak, \& Megginson, 2014).
The rise and growth of Sovereign Wealth Funds reflect a broader phenomenon of equity ownership concentrations within a group of institutional investors rather than in the hands of individuals. Today institutional investors hold around $60 \%$ of all publically listed stock in the United States, around $72 \%$ in Japan and around $89 \%$ in the UK (Çelik \& Isaksson, 2014). There is no commonly accepted definition of an institutional investor thus far; however in the broadest sense, "institutional investor" refers to three categories of entities. The first group of institutional investors refers to traditional institutional investors and comprises pension funds, investment funds and insurance companies. The second group, labeled alternative institutional investors, consists of hedge funds, private equity funds, exchangetraded funds and sovereign wealth funds. The third group are asset managers, who invest in their clients' names (Çelik \& Isaksson, 2014). As a group, institutional investors are regarded as a common feature of modern capital markets, playing the major role in the internationalization of financial markets (Agarwal, 2009). Institutional investors assume an increasing role in global capital markets as well as the main force shaping the new financial landscape (Mizuno, 2010). Given their size, estimations suggest that they account for more than half of global equity market value worldwide, and that when these investors act together, they can shape the financial markets into the form they desire (Rogers, 2014). Foreign institutional investors are quantitatively a very important group especially in emerging markets (Frankel \& Menkhoff, 2003), where they have become a significant channel providing capital (Chang, Hsiao, \& Tsai, 2013). This group of investors is growing fast in emerging markets, where SWFs still predominate as a source of long-term capital (Della Croce, Stewart, \& Yermo, 2011).

Institutional investors as a whole, with Sovereign Wealth Funds playing a significant role, are also the key element of today's global economic and financial landscape, which has been described as a fiduciary capitalism. This term, which was used for the first time by Hawley and Williams, characterizes a new pattern of ownership in which institutions such as e.g. pension funds and mutual funds, own equity on behalf of others e.g. retirees or future retirees (Hawley \& Willams, 1997). The fiduciary capitalism is typified by highly 
diversified equity holdings by a large number of institutional owners, however holdings are in fact, concentrated in the hands of a relatively small number of the very largest entities universal owners (Hawley \& Willams, 2007). These fiduciary institutions, with the Norwegian Sovereign Wealth Fund being a leading example, are highly diversified investors, holding portfolios that represent almost every asset class from almost every regional financial market. Similarly to Sovereign Wealth Funds, other relatively new intuitions have recently become important equity owners alongside the more traditional investors, such as pension funds and investment funds. In a similar vein, Bortolotti et al. (2014) suggest that SWFs are the single most important expression of the force that can be called the rise of the fiduciary state. What makes this phenomenon especially significant is the fact that the largest number of government equity purchases have been acquisitions in foreign companies, where a state purchaser has limited ability to exercise any sovereign regulatory or supervisory power. SWFs as state shareholders have no more authority to monitor target firm managers than do private investors, especially if they are politically constrained.

These developments have given new impetus to the discussion about the role of Sovereign Wealth Funds in publicly listed companies, with special emphasis on the relation between SWFs' ownership, and the financial performance of companies. Due to the fact that in terms of shareholding size, these state-run funds are very different from individual investors, a question arises as to whether institutional ownership influences a company's financial performance. The empirical findings, so far, do not provide clear arguments that allow us to draw unambiguous conclusions on this issue.

\subsection{Institutional Owners and the Financial Performance of a Company}

A large body of research suggests that governments usually have a negative impact on a firm's financial performance, which improves with privatization (Estrin, Hanousek, Kočenda, \& Svejner, 2009; Sun \& Tong, 2003; Shirley \& Walsh, 2001). Sovereign Wealth Funds, due to their political connections, are likely to have objectives other than obtaining the highest possible financial return. Hence, a company with a SWF as a shareholder might be relatively inefficient and experience reductions in their market value, because managers will cater also to the interests of politicians (Fernandes, 2014). In case of public-private ownership, empirical findings of research suggests that such mixed ownership also has a negative impact on the value of the company (Shirley \& Walsh, 2001; Borisova, Brockam, Sales, \& Zagorchev, 2012). However looking at this issue from a different perspective it, is likely that SWFs may be able to increase their performance and the value of the companies they invest in by opening doors to new markets, and by helping them to market their products in their home markets. These state-run funds, due to their long-term investment horizon, can significantly relax financing constraints of firms, thereby allowing them to undertake promising investments with more distant payoffs. Thus, if such advantages are important, one possible outcome is that companies with SWF ownership become more efficient and experience increases in their market value (Fernandes, 2014).

Similar conclusions to those presented above can be drawn from the next strand of literature that focuses on the relation between institutional investor ownership and the financial performance of firms. The prediction that large institutional owners can have a positive influence on the value of the company arises from the assumption that these investors have an incentive to and can efficiently monitor insiders, reducing the likelihood that insiders will make sub-optimal decisions (Navissi \& Naiker, 2006). Woidtke (2002) finds that Tobin's $Q$ is positively related to the ownership proportion of the private pension fund. For public pension funds, such relations were negative. Similarly Cornett, Marcus, Saunders and Tehranian (2007) find a significant relation between a company's operation cash flow returns and both the shareholding proportion and the number of investors, for those institutional investors less likely to have a business relationship with the firms. In a similar vein, the empirical finding of Yuan, Xiao and Zou (2008) suggest that equity ownership by mutual funds has a positive effect of firm performance. Elyasiani and Jia, analyzing the distribution of institutional ownership, have found that there is a positive relationship between company performance and institutional ownership stability (Elyasiani \& 
Jia, 2010). The empirical results presented by Hsu and Wang (2014) show that the increasing stability of institutional holdings is related to better company performance.

On the other hand, the literature provides evidence on the negative relationship between institutional ownership and company performance; e.g. the empirical findings of Liang, Lin and Huang (2011) suggest that institutional shareholdings negatively affect firm performance. Also Charfeddine and Elmarzougui (2010) argue that institutional ownership has a significant negative impact on firm performance as measured by a proxy for Tobin's Q. Ruiz-Mallorquí and SantanaMartín (2011), using a sample of the listed companies in Spain, present evidence that the relationship between institutional investors and firm performance is negative for the banking sector due to the fact that banks in pursuit of achieving profits have detrimental influence on company performance. In contrast, the other studies find no significant relation between the above-mentioned variables (Faccio \& Laser, 2000; Duggal \& Millar 1999). Summing up, the impact of institutional stock ownership on firm performance is still unclear.

While the motives of creating Sovereign Wealth Funds and macroeconomics profits for the domestic economy as well as for transparency and geopolitical concerns are well recognized in the literature (see e.g. Beck \& Fidora, 2008; Sun \& Hesse, 2009; Sedláček, 2010; Quadrio Curzio \& Miceli, 2010; Urban, 2011; Jiránková, 2012; Ćusović, 2012; Castelli \& Scacciavillani, 2012; Alhashel, 2015), many questions concerning the financial aspects of funds' activities still remain relatively unanswered. Moreover, the empirical results found in the literature are controversial with reference to the short versus the long term, as well as to investment and divestment issues which are relatively sparse, mainly due to difficulties in obtaining comprehensive and systematic data (Heaney, Li, \& Valencia, 2011) and information gaps (Ciarlone \& Micelli, 2014).

Knill, Lee and Mauck (2012), looking at the at risk-reward performance of target companies, argue that SWFs do not bring benefits to the companies they invested in, as other institutional investors do. Fotak, Bortolotti, Megginson and Miracky (2008) find evidence suggesting that in the long term these state-run funds are value destroying. Bortolotti, Fotak and Megginson
(2013) argue that companies targeted by active SWFs tend to achieve an abnormal return over the long term, while companies targeted by passive SWFs tend to underperform. Dewenter, Han and Malatesta (2010) suggest that over a five year investment horizon there exists mixed positive evidence on the relation between SWF ownership and the stock performance of targeted firms, which is consistent with Kotter and Lel's (2011) findings of zero-returns over the long run. There are other papers, however, that have found that SWFs bring value to their target firms. The empirical findings regarding the stock performance of target companies suggest that there are positive abnormal returns around the day of investment announcement (Kotter \& Lel, 2011; Fotak, Bortolotti, Megginson, \& Miracky, 2008; Raymond, 2008). In similar vein, Fernandes (2011) argues that there is an SWF premium; companies with the fund as a shareholder have $10-15 \%$ higher values than comparable firms, ceteris paribus. Bertoni and Lugo (2014) find that the Credit Default Spread (CDS) of target companies drops following a SWF's investment. Fernandes (2014) provides statistically significant evidence of both increases in a company's value following SWF investments, as well as significant improvements in operational performance.

Summing up, we can see that the spectrum of empirical findings on the relationship between institutional investors and the financial performance of a target company is very wide and dispersed. Additionally, previous research has been focused mainly on developed markets. Therefore, there is a need for deeper investigation, especially on emerging markets, to reach more robust conclusions.

\section{Methodology and Data 2.1 Sample Selection}

The sample initially comprised all companies listed on the Warsaw Stock Exchange. Three restrictions were then applied. First financial companies (e.g. banks, insurance and financial companies) were excluded as they tend to have capital structures different from other companies. Secondly, the data base was restricted to companies that have been listed for at least one full year as of the end of 2013, to ensure that its performance and the capital structure are not significantly affected by the new listing, which may have an impact on the interpretation of results. Finally, companies with 
missing data have been excluded. The above criteria yielded a usable sample of 336 firms. Within this group, using a unique Sovereign Wealth Funds Institute database, 36 firms were identified as targeted for investment by Sovereign Wealth Funds. The sample of Polish companies represents over $80 \%$ of the total companies from Central and Eastern European Countries that were chosen for investment in 2013. The lack of data for previous years does not allow for the creation of panel data, so far. All financial indicators characterizing listed companies have been obtained from Stock Ground, provided by Notoria Services.

\subsection{Variables}

The key variables of interest are measures of the firm's performance: return on equity (ROE), return on invested capital (ROIC), return on asset (ROA), and Sovereign Wealth Funds' ownership in the company SWF. For SWF we used a dummy variable (SWF_1), and a variable representing the percentage of ownership rights (SWF_2). We also included over $1 \%$ of an ownership variable (SWF_3) to examine the presence of ownership effect after a certain threshold.

Cornett et al. (2007) argue that using operating performance measures may offer some advantages over Tobins' $Q$. First, it is a more focused indicator of the current performance of the company, and unlike Tobins' $Q$, it is not affected by price changes associated with the anticipated corporate takeover events or other growth opportunities. Second, Tobins' $Q$ may be more susceptible to endogeneity problems if investors chase growth stocks or recent market winners. Despite the abovementioned disadvantages, we included a variable $\mathrm{P}$ B BV representing price to book the value of the company. This allowed us to analyze the potential impact of SWF's ownership in the company on its market performance.

In order to control the other possible determinants of company performance, which were not captured by the ownership variable, we also included some observed company characteristics as control variables. The control variables used in the study have been selected with reference to those employed in earlier empirical studies; variables that have been shown to be related to international investment choices (see e.g. Fernandes, 2011). We used the size of the company, its financial leverage, annual stock return, and growth opportunities as the right-hand side variables. The descriptive statistics of variables are presented in Tab. 1.

The size of the company has a significant however ambiguous effect on company performance. On one hand, larger companies can be less efficient than smaller ones because of loss of control by top managers over strategic and operational activities within the firm. On the other hand, large firms may turn out to have better performance as they are likely to exploit economies of scale, employ more skilled managers and have the formalization of procedures (Kumar, 2004). We used the logarithm of total assets (SIZE) to control company size.

The cost of capital derived from leverage being used by the company can affect their financial performance in different ways,

Tab. 1: Descriptive statistics of variables

\begin{tabular}{l|c|c|c|c|c}
\multicolumn{1}{c|}{ Variables } & Obs. & Mean & Std.Dev. & Min & Max \\
\hline ROE & 321 & 1 & 4.026468 & -30.51854 & 36.33857 \\
ROA & 308 & 0.9999 & 2.775469 & -18.38241 & 26.5733 \\
ROIC & 278 & 1 & 4.066483 & -41.64627 & 37.25245 \\
PBV & 333 & 1 & 2.985078 & -1.656082 & 44.28933 \\
SWF_1 & 336 & 0.1071429 & 0.3097561 & 0 & 1 \\
SWF_2 & 336 & 0.2173512 & 0.7663999 & 0 & 5 \\
SWF_3 & 336 & 0.2047917 & 0.7654408 & 0 & 5 \\
PERFORMANCE & 319 & -3.436439 & 13.44888 & -52.7072 & 79.81244 \\
SIZE & 309 & 19.83706 & 1.681403 & 12.97876 & 25.29686 \\
LEVERAGE & 334 & 2.925451 & 31.70677 & -2.290817 & 58.2288 \\
GROWTH_OPP & 317 & 8.460868 & 37.88543 & -99.32204 & 258.5533 \\
\hline
\end{tabular}


including tax shield, a higher business operating risk and highest interest burden (Morck, Shleifer, \& Vishny, 1988). Given this, including this variable (LEVERAGE) in the model seems to be reasonable. We measure leverage as the debt to asset ratio, which equals the book value of total debt divided by the book value of total assets. The lagged annual stock return of the company (PERFORMANCE) is likely to capture the market's expectations on the future performance of the company, and therefore, to account for the possibility that SWFs only select companies with good performance to invest in, we included this variable in the model (Yuan, Xiao, \& Zou, 2008). Therefore, after controlling for this variable, an observed positive coefficient on SWF is more likely to reflect the effect of SWFs' ownership on company financial performance, rather the other way around. The next variable, growth opportunities (GROWTH OPP), reflect the possibility that the fund prefers companies with a higher than average increase of sales, to invest in. Thus, to control for this variable, a sales growth rate is included, similar to that used by Elyasiani and Jia (2010) and Fernandes (2014).

\subsection{The Model}

In order to support a hypothesis about the relationship between SWFs' ownership and the financial performance of the company, we run regressions in which the company's ROE, ROA, ROIC and PBV were a function of various right-hand side variables, discussed in the previous section. The relationship between the investor's capital involvement and the financial performance of the company, however, as previous research suggests, is subject to a potential simultaneity bias. The institutional investors might be attracted to companies with a superior operating performance, and as a consequence of this, a positive association between investors' ownership and financial performance can be observed even if that ownership is not directly beneficial to performance. To eliminate this potential simultaneity bias we employed several tools.

First, we used both accounting and market measures of the financial performance of companies ones as left-hand variables. Secondly, we normalized a company's ROA, ROE, ROIC and P_BV by the market-averages, which eliminated relations between relative performance and a firm's characteristics.
Thirdly, we included a lag variable reflecting return on stock over the previous year, a lag variable of assets and a lag variable of growth opportunities. We also used a lag measure of SWFs' ownership by one year. This lag mitigates simultaneity issues and allowed us to verify the hypothesis that SWFs ownership improves company financial performance over the hypothesis that SWFs increase holdings in companies with better recent financial performance. If SWFs do effect management decisions, and because of that have a positive impact on financial performance target firms, they presumably would do so prior to the year of better performance, which is consistent with the use of a lag.

As a consequence of the adjustments described above, the equations of model regressions are as follows:

$$
\begin{aligned}
& Y_{i, 2014}=\beta_{0}+\beta_{1} S_{W} F_{i, 2013}+\beta_{2} \text { PERFORMANCE } E_{i, 2013}+ \\
& +\beta_{3} \text { SIZE }_{i, 2013}+\beta_{4} \text { LEVERAGE }_{i, 2013}+ \\
& +\beta_{5} \text { GROWTH_OPP } \\
& { }_{i, 2013}+u_{2013}
\end{aligned}
$$

where: $Y_{i, 2014}$ is ROE, ROIC, ROA and P_BV respectively (in the following regressions), and variable $S W F_{i, 2013}$ takes the form of SWF_1, SWF_2 and SWF_3 in each regression for a dependent variable, with $u_{t}$ as the means error term.

Additionally, for each of the dependent variables we also estimated regressions with the use of incremental left-hand variables to analyze the potential influence of SWF ownership on changes in financial performance, rather than on the level of financial variables. Selected estimation results, those arbitrarily chosen to present as best in terms of significance of parameters and $\mathrm{R}^{2}$, are presented in Tab. 2 and Tab. 3. All estimations and calculations have been made with the use of STATA.

\section{Empirical Findings and Discussion}

Looking at the results collectively, we can see the mixed evidence of a relationship between Sovereign Wealth Fund investment and the financial performance of companies. First, in estimations using the absolute level of indicator as a left hand variable, we observe a positive however not statistically significant impact of investment, while in estimations using delta ROE, the relationship seems to be negative. In models: (4), (6) and (8), the variable SWF is statistically significant at $5 \%$ and $1 \%$ 
respectively, suggesting that SWF investment in t-1 year indicates the decrease of return on equity in the following year. The results are consistent with those presented by Knill, Lee and Mauck (2012).

Secondly, the presented empirical results suggest that variable SWF seems to be better in predicting changes of performance rather than an absolute level of indicators. This conclusion seems to be a promising and reasonable avenue for the future research. Thirdly, similar regressions (not reported) have been run with other variables representing the financial performance of company, i.e. return on invested capital, return on assets, as left hand variables. The findings do not provide any evidence to support hypotheses on the relationship between capital involvement of the SWF and the financial performance of the company as well as a robustness test of this analysis. Among several explanations of such a situation, two might be especially important ones. First, a one year lag between funds' investment and measuring changes in financial performance of companies might not be enough for benefits of SWFs' investment to be visible. At the present, due to the database, such a limitation can't be overcome. Further research might also be based on panel data with a wider range of companies from different emerging markets. Secondly, SWFs as new investors in companies might influence managers to act differently with short-term financial performance costs of this change.

As regards to other variables, the level of debt in the company, measured by leverage ratio, has a positive influence of ROE with a statistically significant $1 \%$ level in all regressions. These results as consistent with a theory of finance that points out the positive impact of financial leverage on the financial performance of a company. The variable GROWTH_OPP hold only in $\triangle$ ROE regressions, which suggests that the increase of sales in $\mathrm{t}-1$ year

Tab. 2: SWF ownership and performance of the company (Part 1)

\begin{tabular}{l|c|c|c|c}
\multicolumn{1}{c|}{ Variables } & $\mathbf{( 1 )}$ & $\mathbf{( 2 )}$ & $\mathbf{( 3 )}$ & $\mathbf{( 4 )}$ \\
& $\mathbf{R O E}$ & $\boldsymbol{\Delta}$ ROE & $\mathbf{R O E}$ & $\boldsymbol{\Delta}$ ROE \\
\hline SWF_1 & 0.6008087 & -0.3760626 & - & - \\
& $(0.102)$ & $(0.249)$ & & -0.2818022 \\
SWF_2 & - & - & $(0.013)$ \\
\hline SWF_3 & - & - & - & - \\
\hline PERFORMANCE & 0.047909 & 0.0422848 & 0.484412 & 0.0431408 \\
& $(0.060)$ & $(0.235)$ & $(0.060)$ & $(0.227)$ \\
\hline SIZE & -0.2181708 & -0.0504923 & -0.1877548 & -0.0578668 \\
& $(0.029)$ & $(0.635)$ & $(0.055)$ & $(0.574)$ \\
\hline LEVERAGE & 0.638005 & 0.102362 & 0.63862 & 0.1023649 \\
& $(0.000)$ & $(0.000)$ & $(0.000)$ & $(0.000)$ \\
\hline GROWTH_OPP & 0.005206 & -0.0169462 & 0.006599 & -0.0168639 \\
& $(0.992)$ & $(0.007)$ & $(0.900)$ & $(0.007)$ \\
\hline cons & 5.307779 & 1.163174 & 4.76111 & 1.334118 \\
& $(0.009)$ & $(0.592)$ & $(0.017)$ & $(0.530)$ \\
\hline $\mathbf{R}^{2}$ & 0.4049 & 0.6291 & 0.4023 & 0.6308 \\
\hline Observations & 287 & 280 & 287 & 280 \\
\hline
\end{tabular}

Source: own calculations

Notes: This table presents estimates of coefficients of the regression of ROE and $\triangle R O E$ respectively. Models (1) and (2) present results using a dummy variable for SWF investment that equals 1 if there is equity investment, and 0 otherwise; models (3) and (4) using a percentage of SWF ownership, models (5) and (6) using a percentage of large investment by the fund with threshold restrictions (over 1\%). Models (7) and (8) present estimations with the use of backward- and forward-stepwise selection. All specifications use standard errors corrected for heteroskedasticity. In parentheses are $t$-statistics where a P-value is reported. 
decreases the change of ROE in the following year. Analyzing the portfolio of products and the margin of sales seems to be the natural avenue for future research in order to answer the question on the above relationship.

The coefficient of variable SIZE is negative in all estimations, which suggests that the size of the company measured by the logarithm of assets, has a negative influence on ROE, however the coefficient holds statistical significance only in models (1) and (7). Finally, the variable PERFORMANCE seems to have a positive impact on equity returns, suggesting that the return on a company's stocks in the previous year influences the changes of return on equity the following year, however this hypothesis can't be supported due to a lack of statistical significance of coefficient in all regressions. The $\mathrm{R}^{2}$ is between $40.21 \%$ and $40.49 \%$ for estimations with ROA as a left-hand variable, and from $61.33 \%$ to $63.09 \%$ in models with $\triangle$ ROE.

Contrary to the ambiguous and relatively weak result (in terms of statistical significance)

\section{Tab. 2: SWF ownership and performance of the company (Part 2)}

\begin{tabular}{|c|c|c|c|c|}
\hline Variables & $\begin{array}{c}(5) \\
\text { ROE }\end{array}$ & $\begin{array}{c}(6) \\
\Delta \mathrm{ROE}\end{array}$ & $\begin{array}{c}(7) \\
\text { ROE }\end{array}$ & $\begin{array}{c}(8) \\
\Delta \mathrm{ROE}\end{array}$ \\
\hline SWF_1 & - & - & - & - \\
\hline SWF_2 & - & - & - & - \\
\hline SWF_3 & $\begin{array}{c}0.0450225 \\
(0.724)\end{array}$ & $\begin{array}{c}-0.2910803 \\
(0.010)\end{array}$ & - & $\begin{array}{c}-0.2500814 \\
(0.007)\end{array}$ \\
\hline PERFORMANCE & $\begin{array}{c}0.0485792 \\
(0.059)\end{array}$ & $\begin{array}{c}0.431696 \\
(0.227)\end{array}$ & - & - \\
\hline SIZE & $\begin{array}{c}-0.1857857 \\
(0.058)\end{array}$ & $\begin{array}{c}-0.0608673 \\
(0.554)\end{array}$ & $\begin{array}{c}-0.2593038 \\
(0.009)\end{array}$ & - \\
\hline LEVERAGE & $\begin{array}{c}0.0638692 \\
(0.000)\end{array}$ & $\begin{array}{c}0.1023578 \\
(0.000)\end{array}$ & $\begin{array}{c}0.0598581 \\
(0.000)\end{array}$ & $\begin{array}{c}0.0994049 \\
(0.000)\end{array}$ \\
\hline GROWTH_OPP & $\begin{array}{c}0.0006706 \\
(0.898)\end{array}$ & $\begin{array}{c}-0.168623 \\
(0.007)\end{array}$ & - & $\begin{array}{c}-0.058938 \\
(0.008)\end{array}$ \\
\hline _cons & $\begin{array}{c}4.72861 \\
(0.017)\end{array}$ & $\begin{array}{c}1.392562 \\
(0.513)\end{array}$ & $\begin{array}{c}6.036535 \\
(0.003)\end{array}$ & $\begin{array}{c}-0.0187844 \\
(0.921)\end{array}$ \\
\hline $\mathbf{R}^{2}$ & 0.4021 & 0.6309 & 0.3690 & 0.6133 \\
\hline Observations & 287 & 280 & 287 & 280 \\
\hline
\end{tabular}

Source: own calculations

Notes: This table presents estimates of coefficients of the regression of ROE and $\triangle R O E$ respectively. Models (1) and (2) present results using a dummy variable for SWF investment that equals 1 if there is equity investment, and 0 otherwise; models (3) and (4) using a percentage of SWF ownership, models (5) and (6) using a percentage of large investment by the fund with threshold restrictions (over 1\%). Models (7) and (8) present estimations with the use of backward- and forward-stepwise selection. All specifications use standard errors corrected for heteroskedasticity. In parentheses are $t$-statistics where a $\mathrm{P}$-value is reported.

of the estimations based on the accounting measures of financial performance, the estimations using the market variable $\mathrm{P} B \mathrm{BV}$ seem to provide a relatively clear picture of the relationship between Sovereign Wealth Funds' ownership and the financial performance of the targeted company. In all eight models, the data suggests the positive impact of a fund's ownership on price to book value of the firm. In four models, the coefficient of the SWF variable are statistically significant with $p=1 \%$. It may suggest that, ceteris paribus, companies with SWF as investors have higher market valuations in comparison to the companies not targeted by the fund. The obtained results are consistent with those presented by Fernandes (2014), however in this research the positive impact of ownership is not limited to the variable with threshold restriction. Similarly, as before, a higher level of $R^{2}$ characterizes 


\begin{tabular}{|c|c|c|c|c|}
\hline Variables & $\begin{array}{c}\text { (1) } \\
\text { P_BV }\end{array}$ & $\begin{array}{c}\text { (2) } \\
\text { P_BV }\end{array}$ & $\begin{array}{c}\text { (3) } \\
\text { P_BV }\end{array}$ & $\begin{array}{c}(4) \\
\Delta P_{-} B V\end{array}$ \\
\hline SWF_1 & $\begin{array}{c}0.4145615 \\
(0.004)\end{array}$ & - & - & $\begin{array}{c}0.1428172 \\
(0.027)\end{array}$ \\
\hline SWF_2 & - & $\begin{array}{c}0.0521904 \\
(0.193) \\
\end{array}$ & - & - \\
\hline SWF_3 & - & - & $\begin{array}{c}0.0385772 \\
(0.333)\end{array}$ & - \\
\hline PERFORMANCE & $\begin{array}{c}0.0262617 \\
(0.015)\end{array}$ & $\begin{array}{c}0.0266111 \\
(0.015)\end{array}$ & $\begin{array}{c}0.0266961 \\
(0.015)\end{array}$ & $\begin{array}{c}0.004609 \\
(0.034)\end{array}$ \\
\hline SIZE & $\begin{array}{c}-0.0242915 \\
(0.361)\end{array}$ & $\begin{array}{c}-0.0040284 \\
(0.883) \\
\end{array}$ & $\begin{array}{c}-0.0027371 \\
(0.921) \\
\end{array}$ & $\begin{array}{c}0.020368 \\
(0.134) \\
\end{array}$ \\
\hline LEVERAGE & $\begin{array}{c}0.0150607 \\
(0.000)\end{array}$ & $\begin{array}{c}0.0141023 \\
(0.000)\end{array}$ & $\begin{array}{c}0.014107 \\
(0.000) \\
\end{array}$ & $\begin{array}{c}-0.108721 \\
(0.000) \\
\end{array}$ \\
\hline GROWTH_OPP & $\begin{array}{c}0.0014823 \\
(0.209)\end{array}$ & $\begin{array}{c}0.001585 \\
(0.199)\end{array}$ & $\begin{array}{c}0.0015922 \\
(0.199)\end{array}$ & $\begin{array}{c}0.0008265 \\
(0.139)\end{array}$ \\
\hline _cons & $\begin{array}{c}1.216176 \\
(0.025) \\
\end{array}$ & $\begin{array}{c}0.851187 \\
(0.124) \\
\end{array}$ & $\begin{array}{c}0.8297569 \\
(0.135) \\
\end{array}$ & $\begin{array}{c}-0.2030655 \\
(0.459) \\
\end{array}$ \\
\hline $\mathbf{R}^{2}$ & 0.3641 & 0.3466 & 0.3457 & 0.9894 \\
\hline Observations & 289 & 289 & 289 & 289 \\
\hline
\end{tabular}

Notes: This table presents estimates of coefficients of the regression of price to book value ratio $\left(P \_B V\right)$ and $\Delta P \_B V$ respectively. Models (1) and (4) present results using a dummy variable for SWF investment that equals 1 if there is equity investment, and 0 otherwise, models (2) and (5) using a percentage of SWF ownership, models (3) and (6) using a percentage of large investment by the fund with threshold restrictions (over 1\%). Models (7) and (8) preset estimations with the use of backward- and forward-stepwise selection. All specifications use standard errors corrected for heteroskedasticity. In parentheses are $t$-statistics where a P-value is reported.

those regressions with deltas as the left-hand variables. Regression models (4), (5), (6) and (8) fit a given set of data relatively well $\left(R^{2}\right.$ close to $99 \%$ ).

Additionally, several estimations (not reported in this paper) were run using a different market indicator of a company's financial performance. In regressions with a market capitalization variable as well as with an enterprise value variable, the variable SWF_1 had statistical significance, however the coefficients had a negative sign.

Summing up, the empirical findings of this research along with previous analysis point to difficulties in measuring the impact of Sovereign Wealth Funds' ownership on financial performance and the value of a company, especially with the use of accounting indicators. Furthermore, the market data for companies does not provide clear evidence on the nature of such a relationship. Thus the impact of SWF ownership on company performance seems to remain one of an unsolved puzzle in the field of contemporary finance.

\section{Conclusions}

The motivation of this study was to shed some light onto the debate about the relationship between Sovereign Wealth Fund ownership and the financial performance of the company. The empirical findings of this research, although consistent with previous ones, does not provide clear evidence of the examined relation. However the impact of the fund on the company listed on the emerging market seems to be similar to the relation that can be observed in developed markets. Among issues for future research is the use of panel data and the conduction of a comparative study for industry specific issues based on larger data 
Tab. 3: SWF ownership and price to book value of the company (Part 2)

\begin{tabular}{|c|c|c|c|c|}
\hline Variables & $\begin{array}{c}(5) \\
\Delta P_{-} B V\end{array}$ & $\begin{array}{c}(6) \\
\Delta P_{-} B V\end{array}$ & $\begin{array}{l}\text { (7) } \\
\text { P_BV }\end{array}$ & $\begin{array}{c}(8) \\
\Delta P_{-} B V\end{array}$ \\
\hline SWF_1 & - & - & $\begin{array}{c}0.3833516 \\
(0.008)\end{array}$ & $\begin{array}{c}0.1713876 \\
(0.006)\end{array}$ \\
\hline SWF_2 & $\begin{array}{c}0.187211 \\
(0.545)\end{array}$ & - & - & - \\
\hline SWF_3 & - & $\begin{array}{c}0.0140063 \\
(0.646) \\
\end{array}$ & - & - \\
\hline PERFORMANCE & $\begin{array}{c}0.00472 \\
(0.032) \\
\end{array}$ & $\begin{array}{c}0.0047543 \\
(0.031) \\
\end{array}$ & $\begin{array}{c}0.0270857 \\
(0.014)\end{array}$ & - \\
\hline SIZE & $\begin{array}{c}0.0273018 \\
(0.044) \\
\end{array}$ & $\begin{array}{c}0.0277562 \\
(0.040) \\
\end{array}$ & - & - \\
\hline LEVERAGE & $\begin{array}{c}-0.1087068 \\
(0.000)\end{array}$ & $\begin{array}{c}0.0141023 \\
(0.000)\end{array}$ & $\begin{array}{c}0.140907 \\
(0.000)\end{array}$ & $\begin{array}{c}0.1090741 \\
(0.000)\end{array}$ \\
\hline GROWTH_OPP & $\begin{array}{l}0.0007915 \\
(0.165)\end{array}$ & $\begin{array}{c}0.000789 \\
(0.168)\end{array}$ & - & - \\
\hline _cons & $\begin{array}{c}-0.3280275 \\
(0.231) \\
\end{array}$ & $\begin{array}{c}-0,335631 \\
(0.220) \\
\end{array}$ & $\begin{array}{c}0.7511153 \\
(0.000)\end{array}$ & $\begin{array}{c}0.1758946 \\
(0.000) \\
\end{array}$ \\
\hline $\mathbf{R}^{2}$ & 0.9893 & 0.9892 & 0.3591 & 0.9892 \\
\hline Observations & 289 & 289 & 289 & 289 \\
\hline
\end{tabular}

Source: own calculations

Notes: This table presents estimates of coefficients of the regression of price to book value ratio $\left(P \_B V\right)$ and $\Delta P \_B V$ respectively. Models (1) and (4) present results using a dummy variable for SWF investment that equals 1 if there is equity investment, and 0 otherwise, models (2) and (5) using a percentage of SWF ownership, models (3) and (6) using a percentage of large investment by the fund with threshold restrictions (over 1\%). Models (7) and (8) preset estimations with the use of backward- and forward-stepwise selection. All specifications use standard errors corrected for heteroskedasticity. In parentheses are $\mathrm{t}$-statistics where a $\mathrm{P}$-value is reported.

set. This analysis could provide a robust test on the relationship between a fund's ownership and the financial performance of firms that are of interest to the managers of companies as well to policy makers and researchers.

\section{References}

Agarwal, P. (2009). Institutional Ownership and Stock Liquidity. Ithaca, NY: Cornell University.

Alhashel, B. (2015). Sovereign Wealth Funds: A Literature Review. Journal of Economics and Business, 78, 1-13. doi:10.1016/j.jeconbus.2014.10.001.

Beck, R., \& Fidora, M. (2008). The Impact of Sovereign Wealth Funds on Global Financial Markets. European Central Bank Occasional Paper Series, 91, 1-30.

Bertoni, F., \& Lugo, S. (2014). The effect of sovereign wealth funds on the credit risk of their portfolio companies. Journal of Corporate Finance, 27, 21-35. doi:10.1016/j.jcorpfin.2014.04.004.

Borisova, G., Brockman, P., Sales, J., \& Zagorchev, A. (2012). Government ownership and corporate governance: Evidence from the EU. Journal of Banking and Finance, 36, 29172934. doi:10.1016/j.jbankfin.2012.01.008.

Bortolotti, B., Fotak, V., \& Megginson, W. (2014). The Rise of Sovereign Wealth Funds: Definition, Organization and Governance. BAFFI Center Research Paper Series, 163, 1-26.

Castelli, M., \& Scacciavillani, F. (2012). The New Economics of Sovereign Wealth Funds. Chichester: Wiley Finance.

Çelik, S., \& Isaksson, M. (2014). Institutional investors and ownership engagement. OECD Journal: Financial Market Trends, 2, 93-114.

Chang, L-L., Hsiao, F. D., \& Tsai, Y-Ch. (2013). Earnings, institutional investors, tax 
avoidance and firm value: Evidence from Taiwan. Journal of International Accounting Auditing and Taxation, 22(2), 98-108. doi:10.1016/j.intaccaudtax.2013.07.001.

Charfreddine, L., \& Elmarzougui, A. (2010). Institutional Ownership and Firm Performance: Evidence from France. The IUP Journal of Behavioral Finance, 7(4), 35-46.

Ciarlone, A., \& Micelli, V. (2014). Are Sovereign Wealth Funds contrarian investors? [Banca D'Italia Working Papers, 972].

Cornett, M. M., Marcus, A. J., Saunders, A., \& Tehranian, H. (2007). The impact of institutional ownership on corporate operating performance. Journal of Banking and Finance, 31, 1771-1794. doi:10.1016/j.jbankfin.2006.08.006.

Ćusović, D. (2012). Sovereign wealth funds in the globalization of financial markets. Perspectives of Innovations, Economics and Business, 10(1), 5-13. doi:10.15208/pieb.2012.01.

Della Croce, R., Stewart, F., \& Yermo, J. (2011). Promoting longer-term investment by institutional investors: selected issues and policies. OECD Journal: Financial Market Trends, 1, 1-20. doi:10.1787/19952872.

Dewenter, K., Han, X., \& Malatesta, P. (2010). Firm values and sovereign wealth funds investments. Journal of Financial Economics, 98(2), 256-278. doi:10.1016/j. jfineco.2010.05.006.

Duggal, R., \& Millar, J. (1999). Institutional ownership and firm performance: The case of bidder returns. Journal of Corporate Finance, 5 , 103-117. doi:10.1016/S0929-1199(98)00018-2.

Elyasiani, E., \& Jia, J. (2010). Distribution of institutional ownership and corporate firm performance. Journal of Banking \& Finance, 34, 606-620. doi:10.1016/j.jbankfin.2009.08.018.

Estrin, S., Hanousek, J., Kočenda, E., \& Svejnar, J. (2009). The effects of privatization and ownership in transition economies. Journal of Economic Literature, 47(3), 699-728. doi:10.1257/jel.47.3.699.

Faccio, M., \& Lasfer, M. (2000). Do occupational pension funds monitor companies in which the hold large stakes? Journal of Corporate Finance, 6, 71-110. doi:10.1016/S0929-1199(99)00016-4.

Fernandes, N. (2014). The Impact of Sovereign Wealth Funds on Corporate Value and Performance. Journal of Applied Corporate Finance, 26(1), 76-84. doi:10.1111/jacf.12056.

Fernandes, N. (2011). Sovereign Wealth Funds: Investment Choices and Implications around the World. IMD International, 1, 1-48.
Fotak, V., Bortolotti, B., \& Megginson, W. (2013). The Sovereign Wealth Fund Discount: Evidence from Public Equity Investment. Paolo Baffi Centre Research Paper Series, 140, 1-57.

Fotak, V., Bortolotti, B., Megginson, W., \& Miracky, W. (2008). The financial impact of sovereign wealth funds investment in listed companies [Unpublished working paper]. University of Oklahoma and Univeristà di Torino.

Frenkel, M., \& Menkhoff, L. (2003). Are foreign institutional investors good for emerging markets? Discussion Paper, 283, 1-30. doi:10.1111/j.1467-9701.2004.00646.x.

Hawley, J. P., \& Willams, A. T. (1997). The Emergence of Fiduciary Capitalism. Corporate Governance, 5(4), 206-213. doi:10.1111/1467-8683.00062.

Hawley, J. P., \& Willams, A. T. (2007). Universal Owners: challenges and opportunities. Corporate Governance, 15(3), 415-420. doi:10.1111/j.1467-8683.2007.00574.x.

Heaney, R., Li, L., \& Valencia, V. (2011). Sovereign Wealth Funds Investment Decisions: Temasek Holdings. Australian Journal of Management, 36(1), 109-120. doi:10.1177/0312896210388859.

Hsu, M- F., \& Wang, K. (2014). The Level and Stability of Institutional Ownership and Firm Performance: Evidence from Taiwan. Emerging Markets Finance \& Trade, 50, 159-173. doi:10.2753/REE1540-496X5002S211.

Jiránková, M. (2012). Nation-States as Investors in a Globalized World. Ekonomický časopis / Journal of Economics, 60(8), 854-870.

Knill, A., Lee, B., \& Mauck, N. (2012). Sovereign wealth funds investment and the return to risk performance of target firms. Journal of Financial Intermediation, 21(2), 315-340. doi:10.1016/j.jfi.2011.10.001.

Kotter, J., \& Lel, U. (2011). Friends of foes? Target selection decisions of sovereign wealth funds and their consequences. Journal of Financial Economics, 101(2), 360-381. doi:10.1016/j.jfineco.2011.03.007.

Kumar, J. (2004). Does Ownership Structure Influence Firm Value? Evidence from India. The Journal of Entrepreneurial Finance and Business Venture, 9(2). 61-93.

Liang, C. J., Lin, Y. L., \& Huang, T. T. (2011). Does endogenously determined ownership matter on performance? Dynamic evidence from emerging Taiwan market. Emerging Markets Finance and Trade, 47(6), 120-133. doi:10.2307/41343444. 
Mizuno, M. (2010). Institutional investors, corporate governance and firm performance in Japan. Pacific Economic Review, 15(5), 653665. doi:10.1111/j.1468-0106.2010.00521.x.

Morck, R., Shleifer, A., \& Vishny, R. (1988). Management ownership and market valuation: An empirical analysis. Journal of Financial Economics, 20, 293-315. doi:10.1016/0304405X(88)90048-7.

Navissi, F., \& Naiker, V. (2006). Institutional ownership and corporate value. Managerial Finance, 32(3), 247-256. doi:10.1108/03074350610646753.

Quadrio Curzio, A., \& Miceli, V. (2010). Sovereign Wealth Funds: A Complete Guide to State-Owned Investment Funds. Petersfield: Harriman Finance Essentials.

Raymond, H. (2008). The effect of Sovereign Wealth Funds' involvement on stock markets. Bank of France Occasional Paper, 7, 1-17. doi:10.1016/S2110-7017(13)60016-5.

Rogers, J. (2014). A New Era of Fiduciary Capitalism? Let's hope so. Financial Analyst Journal, 70(3), 6-11.

Ruiz-Mallarquí, M. V., \& Santana-Martín, D. J. (2011). Dominant Institutional Owners and Firm Value. Journal of Banking and Finance, 35(1), 118-129. doi:10.1016/j.jbankfin.2010.07.020.

Sedláček, P. (2010). Státní investiční fondy - významný institucionální investor globálních finančních trhů. Acta Oeconomica Pragensia, 18(2), 3-22.
Shirley, M., \& Walsh, P. (2001). Public vs. private ownership: The current state of the debate [World Bank Working Paper, 2420].

Sun, Q., \& Tong, W. (2003). China's share issue privatization: The extent of its success. Journal of Financial Economics, 70(2), 183-222. doi:10.1016/S0304-405X(03)00145-4.

Sun, T., \& Hesse, H. (2009). Sovereign Wealth Funds and Financial Stability - An Even Study Analysis [IMF Working Paper, 239]. doi:10.5089/9781451873863.001.

Urban, D. (2011). The Role of Sovereign Wealth Funds in Global Management of Excess Foreign Exchange Reserves. Comparative Economic Research Central and Eastern Europe, 14(2), 143-158.

Woidtke, T. (2002). Agents watching agents? Evidence from pension funds ownership and firma value. Journal of Financial Economics, 63, 99-131. doi:10.1016/S0304405X(01)00091-5.

Yuan, R., Xiao, J. Z., \& Zou, H. (2008). Mutual funds' ownership and firm performance: Evidence from China. Journal of Banking and Finance, 32(8), 1552-1565. doi:10.1016/j.jbankfin.2007.08.001.

Dariusz Urban, PhD University of Lodz Faculty of Management Department of Finance and Strategic Management durban@uni.lodz.pl 


\section{Abstract}

\section{THE IMPACT OF SOVEREIGN WEALTH FUND OWNERSHIP ON THE FINANCIAL PERFORMANCE OF FIRMS: THE EVIDENCE FROM EMERGING MARKETS}

\section{Dariusz Urban}

Sovereign Wealth Funds have been regarded as investment vehicles established in order to manage, in a rational and profit-oriented way, pools of national wealth for future generations. SWFs are among the most important financial institutions in global financial markets, and constitute a solid element in the architecture of the international financial safety net. Similarly to other institutional investors, Sovereign Wealth Funds possess huge amounts of capital. What distinguishes them the most from other financial institutions is the fact that they are owned, managed and controlled by sovereign states, have limited liquidity needs, a lower-than-market-average-level of redemption risk, a long-term, intergenerational investment horizon and relatively high risk tolerance. The question of whether investment from Sovereign Wealth Funds determines changes in corporate financial performance of a targeted firm is still unanswered question in the literature. This study tests empirically the impact of Sovereign Wealth Funds' ownership on the financial performance of targeted companies. Using the data of companies listed on the Warsaw Stock Exchange, we employ regression to analyze the relationship between the funds' investment and accounting, as well as the market outcomes of the firm. The empirical findings of this research suggest that Sovereign Wealth Funds' ownership has a positive influence on the price to book value of the firm. This article contributes to ongoing research in the field of studies related to financial aspects of SWF's investment behavior. The empirical findings of this research can also serve as a useful reference for companies and academics concerning themselves with investment decision making in emerging markets, as well as the role of institutional investors.

Key Words: Sovereign wealth funds, institutional investor, financial performance, investing, emerging economies.

JEL Classification: G11, G23, C13, F21.

DOI: 10.15240/tul/001/2017-3-012 